\title{
Resolution of complex ends by non-homologous end joining - better to be lucky than good?
}

\author{
Natasha Tiffany Strande, Crystal Ann Waters and Dale A Ramsden*
}

\begin{abstract}
The non-homologous end joining pathway is essential for efficient repair of chromosome double strand breaks. This pathway consequently plays a key role in cellular resistance to break-inducing exogenous agents, as well as in the developmentally-programmed recombinations that are required for adaptive immunity. Chromosome breaks often have complex or "dirty" end structures that can interfere with the critical ligation step in this pathway; we review here how non-homologous end joining resolves such breaks.
\end{abstract}

Keywords: Double strand break repair, non-homologous end joining, DNA damage, lonizing radiation

\section{Double strand break repair and complex end structures}

DNA double strand breaks (DSBs) arise after replication, aberrant repair of spontaneous damage, and exposure to exogenous damaging agents, especially those used in cancer therapies. DSBs are also intermediates in several developmentally-programmed recombinations. Failed DSB repair is typically lethal, while aberrant DSB repair can lead to developmental defects, progeria, and cancer. Repair pathways include Homologous recombination (HR), non-homologous end joining (NHEJ), and Alternate end joining (Alt-EJ) (reviewed in e.g. [1]). Importantly, HR is dependent on extensive (100s to 1000s of nucleotides) DNA synthesis, a sister chromatid template to direct this synthesis, and a homology search step needed to find the template in a sister chromatid. In contrast, NHEJ is primarily a ligation reaction and can act independently of S-phase restricted sister chromatids, dNTP generation [2], and other requirements for extensive synthesis. Finally, a fraction of ligationmediated repair is independent of factors required for classically defined NHEJ, and is thus termed "Alt-EJ".

The primary disadvantage to resolving ends by ligation is that biological sources of DSBs often produce "dirty" or complex end structures that can interfere with this step (Figure 1). DNA flanking the break may possess

\footnotetext{
* Correspondence: dale_ramsden@med.unc.edu

Lineberger Comprehensive Cancer Center, Department of Biochemistry and Biophysics and Curriculum in Genetics and Molecular Biology, University of North Carolina, Chapel Hill, North Carolina 27599, USA
}

nucleotide damage, most frequently oxidized bases, various classes of abasic sites, and $3^{\prime}$ phosphate or $5^{\prime}$ hydroxyl termini [3]. Such damage is especially likely in the case of ionizing radiation-induced breaks, which are associated with damage clusters $[3,4]$. DSB ends may be further occluded by proteins, both non-covalently associated (e.g. chromatin) and covalently adducted type II topoisomerases [5]. Ends can also possess secondary structures including hairpins or, after a pair of ends are aligned together, gaps, mismatches, or flaps.

NHEJ resolves complex ends by employing a sophisticated machine engineered to facilitate ligation despite ligation-blocking lesions. A series of core factors are necessary and sufficient to recognize ends, align a pair of ends together, and perform the ligation step (Figure 2). Core factors include 1) Ku; a DNA end binding heterodimer of 70 and $80 \mathrm{kD}$ subunits (Ku70, Ku80), 2) XRCC4-ligase IV (X4-LIV); an obligate oligomer of a ligase catalytic subunit (DNA ligase IV) and scaffolding subunit (XRCC4), 3) XRCC4-like factor (XLF, also termed Cernunnos), and 4) DNA dependent protein kinase catalytic subunit (DNA-PKcs); a $450 \mathrm{kD}$ kinase recruited to ends by $\mathrm{Ku}$ (reviewed in [6]). However, additional factors are required, both to integrate NHEJ with the DNA damage response and local chromatin structure [7], as well as (to be discussed here) to help this core machine resolve complex ends (Table 1). NHEJ employs these additional factors according to strategies (Figure 2) for resolving complex ends we suggest can be 


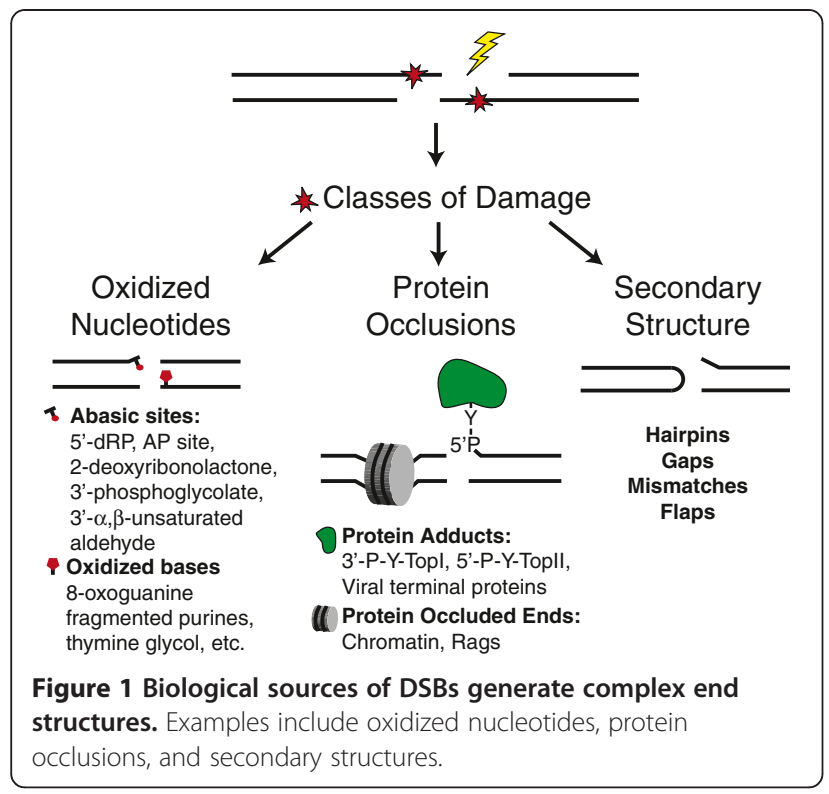

roughly categorized as 1) tolerance (Figure 3 ), 2) end "cleaning" (Figure 4), and 3) trial-and-error (Figure 5).

Tolerance of complex ends by low fidelity ligation Ligation initiates with the transfer of an adenosine monophosphate from a lysine within the ligase active site to the $5^{\prime}$ phosphate (Figure 3, step ii). The final step in ligation has similarities to DNA synthesis, as the new phosphodiester bond is made by a phosphoryl transfer reaction, where the $3^{\prime}$ hydroxyl terminus of one strand

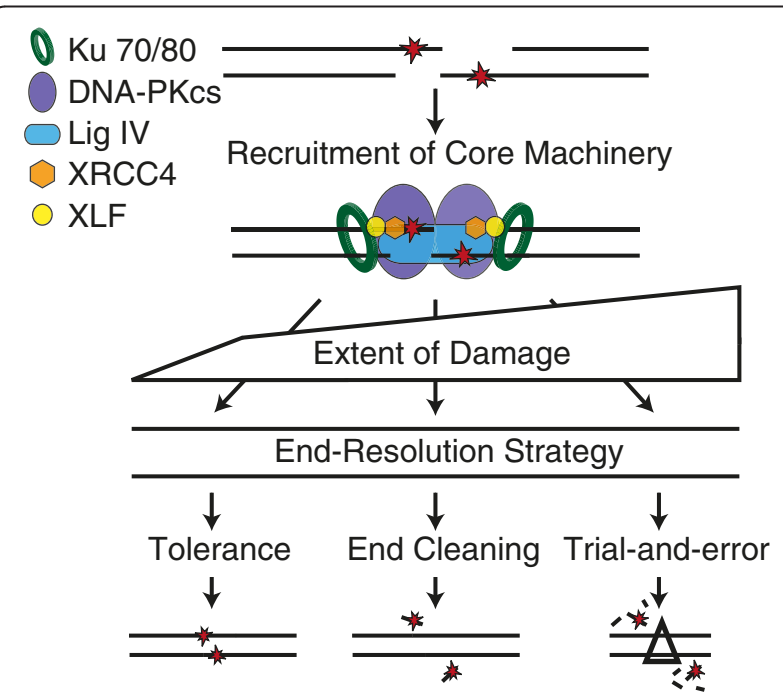

Figure 2 NHEJ end-resolution strategies. Resolution of complex ends by NHEJ first requires the recruitment of the core machinery (Ku, DNA-PKCS, Ligase IV, XRCC4, and XLF). The type and extent of damage varies, and this in turn probably dictates choice of strategy.
Table 1 End processing factors

\begin{tabular}{|c|c|}
\hline Factor* & Activity \\
\hline$\overline{\text { APTX }}$ & Removes 5'-adenylate adducts [40] \\
\hline$\overline{P N K P}$ & $\begin{array}{l}\text { Removes } 3 \text { ' phosphates and phosphorylates } 5^{\prime} \\
\text { hydroxyls [45] }\end{array}$ \\
\hline$\overline{\text { APLF }}$ & $\begin{array}{l}\text { Histone chaperone [59] } 3^{\prime}-5^{\prime} \text { exonuclease, } \\
\text { endonuclease }[56,61]\end{array}$ \\
\hline$\overline{T D P 1}$ & $\begin{array}{l}\text { Removes Top I adducts [63], 3' deoxyribose } \\
\text { fragments }[47,67,68]\end{array}$ \\
\hline TDP2 & Removes Top II adducts [64] \\
\hline XRCC5,XRCC6 (Ku) & Removes 5'-dRP residues and abasic sites [27] \\
\hline POLM (Pol $\lambda)$ & $\begin{array}{l}\text { Fills in gaps when ends align with no } \\
\text { complementarity [90] }\end{array}$ \\
\hline$\overline{\text { POLL }(\mathrm{Pol} \mu)}$ & $\begin{array}{l}\text { Fills in gaps when ends are partly complementary } \\
{[86,90]}\end{array}$ \\
\hline DCLRE1C (Artemis) & Endonuclease, $5^{\prime}-3^{\prime}$ exonuclease [100] \\
\hline$\overline{\text { WRN }}$ & $3^{\prime}-5^{\prime}$ exonuclease $[121,122]$ and $3^{\prime}-5^{\prime}$ helicase $[120]$ \\
\hline $\begin{array}{l}\text { MRE11/RAD50/NBN } \\
\text { (MRN) }\end{array}$ & $3^{\prime}-5^{\prime}$ exonuclease, endonuclease $[101,129]$ \\
\hline SETMAR (Metnase) & Endonuclease/exonuclease [103] \\
\hline \multicolumn{2}{|c|}{$\begin{array}{l}\text { *HUGO gene nomenclature: } A P T X \text {, aprataxin; } P N K P \text {, polynucleotide kinase 3'- } \\
\text { phosphatase; } A P L F \text {, aprataxin and PNKP like factor; TDP1, tyrosyl-DNA } \\
\text { phosphodiesterase } 1 ; T D P 2 \text {, tyrosyl-DNA phosphodiesterase 2; XRCC5,XRCC6 } \\
\text { (Ku80, Ku70), X-ray repair complementing defective repair in Chinese hamster } \\
\text { cells 5/6; POLM, polymerase mu; POLL, polymerase lambda; DCLRE1C (Artemis), } \\
\text { DNA cross-link repair } 1 C ; \text { WRN, Werner syndrome; MRE11/RAD50/NBN, meiotic } \\
\text { recombination } 11 \text { homolog/RAD50 homolog/nibrin (Nbs1), SETMAR, SET } \\
\text { domain and mariner transposase fusion gene (Metnase). }\end{array}$} \\
\hline
\end{tabular}

performs a nucleophillic attack on the activated $5^{\prime}$ phosphate terminus of the second (Figure 3, step iii) (reviewed in [8]). Importantly, most DNA ligases resemble polymerases in that they are most active when joining strands with termini complementary to a "template" strand. Thus, in the same manner as polymerases, ligases can be considered as high or low fidelity according to the degree to which they tolerate mispairs or other helix distortions in DNA flanking the bond to be made.

\section{The XLF-X4-LIV splint and low fidelity ligation}

X4-LIV can join together strand termini with flanking mispairs more readily than other ligases $[9,10]$, and thus can be considered to be of low fidelity. Importantly, XLF specifically promotes low-fidelity ligation $[11,12]$. Dimers of XLF interact with dimers of XRCC4 and DNA [13-18], resulting in DNA- bound (XLF-XRCC4) $)_{\mathrm{N}}$ filaments $[14,19-23]$ that eventually include or terminate in a X4LIV complex (Figure 3, step i). These filaments are thought to act as a protein-"splint", stabilizing an aligned pair of ends. The splint could account for reduced ligation fidelity by suppressing helix distortions associated after alignment of complex end structures, or by simply increasing the time the active site has to work with end alignments with poorly oriented termini. Low-fidelity ligation is advantageous for NHEJ as it increases the 
spectrum of complex ends that can be ligated together directly without prior end processing.

However, there is a limit to what NHEJ's ligase can tolerate [9,24-30], even with the XLF-X4-LIV splint. Notably, DNA-PKcs-mediated phosphorylation of multiple sites within XLF and XRCC4 disrupts the filament (Figure 3, step v) [31]. This may relax (or release) unproductive complexes of the ligase and aligned ends to give better access to end processing enzymes required for other NHEJ strategies (e.g, Figures 4, 5).

Additionally, like damage tolerance by translesion polymerases in replication, tolerance of complex end structures by NHEJ is a form of procrastination - mismatched and damaged nucleotides flanking the break site are not repaired and thus retained in the joined product (junction). Unresolved damage will interfere with subsequent transcription or replication through the junction. Additionally, attempted repair by other pathways (e.g. base excision repair; BER) of residual damage clusters in junctions risks re-breaking the site [32-36]. Sustained localization of NHEJ factors (e.g. Ku, X4-LIV, XLF) after joining may even help regulate BER activity.

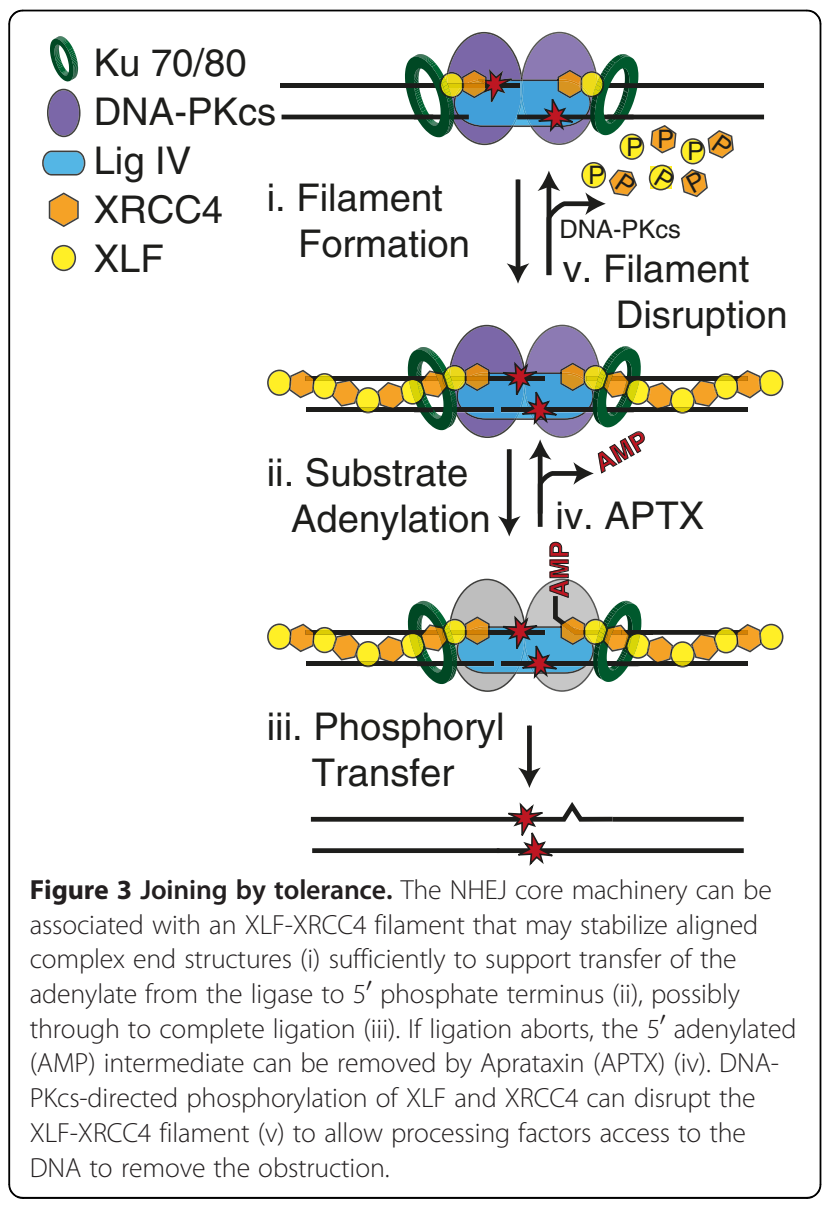

\section{Damage-specific end cleaning}

Ligases cannot join ends unless they have $5^{\prime}$ phosphate and $3^{\prime}$ hydroxyl termini, regardless of how stably a pair of aligned termini are juxtaposed. In addition, NHEJ's ligation step is blocked by terminal or near-terminal abasic sites [24-27,29] and when lesions or mismatches in end structures are sufficiently helix distorting. Common terminus-blocking lesions can be excised and the potentially resulting gaps filled in before ligation (Figure 4). As with other repair pathways (e.g. BER), NHEJ can thus fully restore sequence at DSB sites, even when the break was associated with ligation blocking damage [24].

To this end, NHEJ employs an array of enzymes that partly overlap with BER and single strand break repair (SSBR). Indeed, three of these factors - aprataxin (APTX), polynucleotide kinase/phosphatase (PNKP), and aprataxin and polynucleotide kinase/phosphatase like factor (APLF) - employ N-terminal forkhead associated (FHA) domains to mediate their participation in both NHEJ and BER/SSBR pathways (reviewed in [37]). These domains physically interact with XRCC4 [38] and XRCC1 [39] to direct their participation in NHEJ and BER/SSBR, respectively. FHA domain-mediated interactions are stimulated by phosphorylation of XRCC4 and $\mathrm{XRCC} 1$ by casein kinase II.

\section{Aprataxin}

As noted above, there is a limit to what the ligase can tolerate. Attempts to tolerate complex end structures can result in ligation failure at an intermediate step, after adenylation of the $5^{\prime}$ terminus but before the final phosphoryl transfer (Figure 3, step ii). A new ligase IV molecule cannot act on the $5^{\prime}$ adenylated product of aborted ligation; Aprataxin (APTX) resets the substrate for another ligation attempt by removing 5 -adenylate adducts (Figure 3, step iv), as mediated by APTX's zinc-fingerhistidine triad (HIT) domain [40].

Mutations in APTX account for several neurodegenerative disorders, including ataxia with oculomotor apraxia type 1 (AOA1) [41,42]. However, sensitivity of APTX deficient cells to various DNA damaging agents is mild [43], and it has been difficult to detect measurable differences in either SSBR or DSBR ([44] and references therein). APTX is thus argued to act on a minor subset of breaks [44], with the consequences of failed action in an organism possibly disproportionate to the low frequency of these events.

\section{Polynucleotide kinase/phosphatase}

$5^{\prime}$ hydroxyl and $3^{\prime}$ phosphate termini are generated directly by reactive oxygen species, after metabolization of certain strand breaks (3'- phosphoglycolate, 3'-phosphotyrosine), or by the action of endo-VIII-like glycosylases (Neil1 or Neil2). PNKP has two catalytic domains sufficient to 


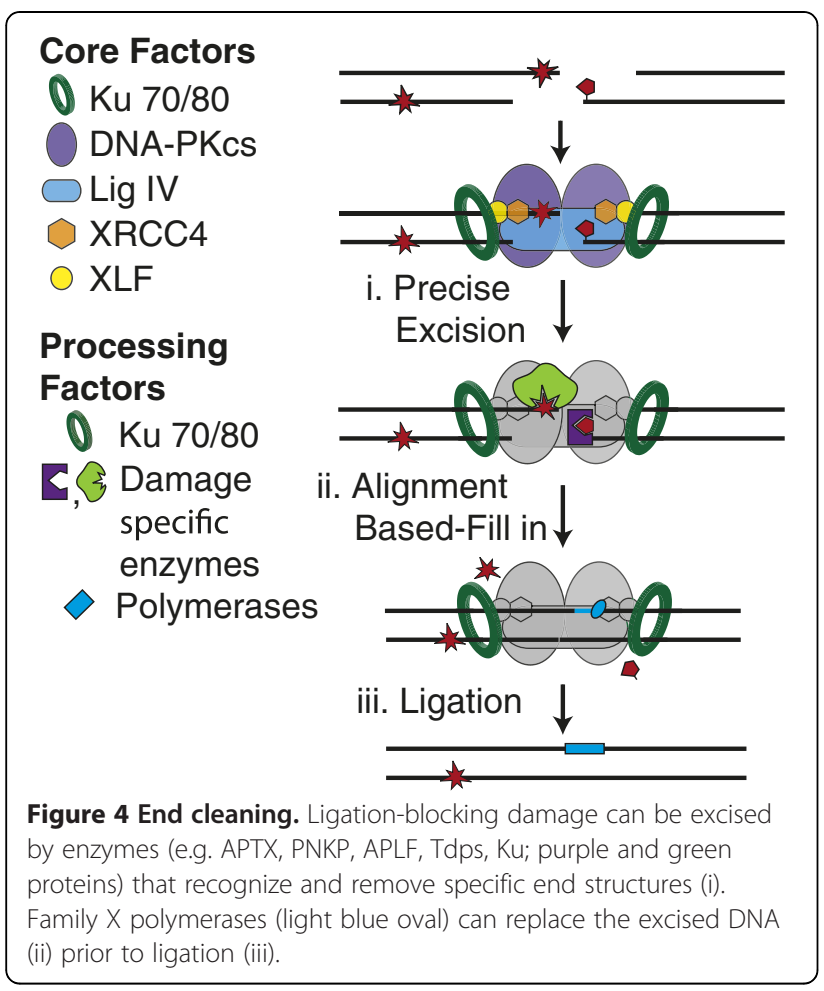

prepare such termini for ligation: a central domain that removes $3^{\prime}$ phosphates, and a $\mathrm{C}$-terminal domain that phosphorylates $5^{\prime}$ hydroxyls [45] (reviewed in [46]). PNKP was also shown to act coordinately with TDP1 to remove the $3^{\prime}$ phosphate generated after removal of $3^{\prime}$ phosphoglycolate residues [47].

Mutations in PNKP result in microcephaly with early onset intractable seizures and developmental delay (MCSZ) [48]. A role for PNKP specifically in double strand break repair is supported by sensitivity of PNKP deficient cells to ionizing radiation $[48,49]$, and PNKP is required for NHEJ of ends without $5^{\prime}$ phosphate in cell extracts [50]. PNKP's contribution to radiation sensitivity relies to some extent on damage-dependent phosphorylation of sites in PNKP by DNA-PKcs and ATM $[51,52]$.

\section{Aprataxin and polynucleotide kinase/phosphatase like factor}

APLF (also referred to as PALF, C2orf13, and Xip1) possesses a tandem pair of poly(ADP-ribose) binding zinc finger (PBZ) motifs [53], which mediate recruitment of APLF to damage [54-57] after poly(ADP) ribose polymerase-3 (PARP-3) modification of flanking chromatin [58]. Disruption of APLF's PBZ domains attenuates X4-LIV accumulation at DSB ends in cells, which in turn results in defects in NHEJ of radiation induced breaks and DSB intermediates in class switch recombination [58]. This may be at least partly because a network of interactions between APLF, Ku [56,57], X4-LIV [57,58], DNA, and poly(ADP-ribose) chromatin $[57,58]$ could be required for stable assembly of an NHEJ complex at ends. APLF also possesses a conserved C-terminal domain with a NAP1L family histone chaperone motif, which is sufficient to promote assembly and disassembly of nucleosomes and nucleosome substructures in vitro [59]. Ku can recognize DSB ends even when on the surface of a nucleosome [28], but an active NHEJ complex, including X4-LIV and DNA-PKcs, requires at least $60 \mathrm{bp}$ of free DNA flanking the end [60] (probably more with an (XLF-X4) $)_{\mathrm{N}}$ splint). APLF, perhaps triggered by coordinate recognition of ends by Ku and PBZ mediated interactions with flanking poly(ADP-ribose) modified chromatin, could direct a very limited remodeling of nucleosomes flanking broken ends to make room for subsequent loading of X4-LIV. APLF may additionally act as an exonuclease and structure-specific endonuclease $[56,61]$ to resolve mismatches and flaps.

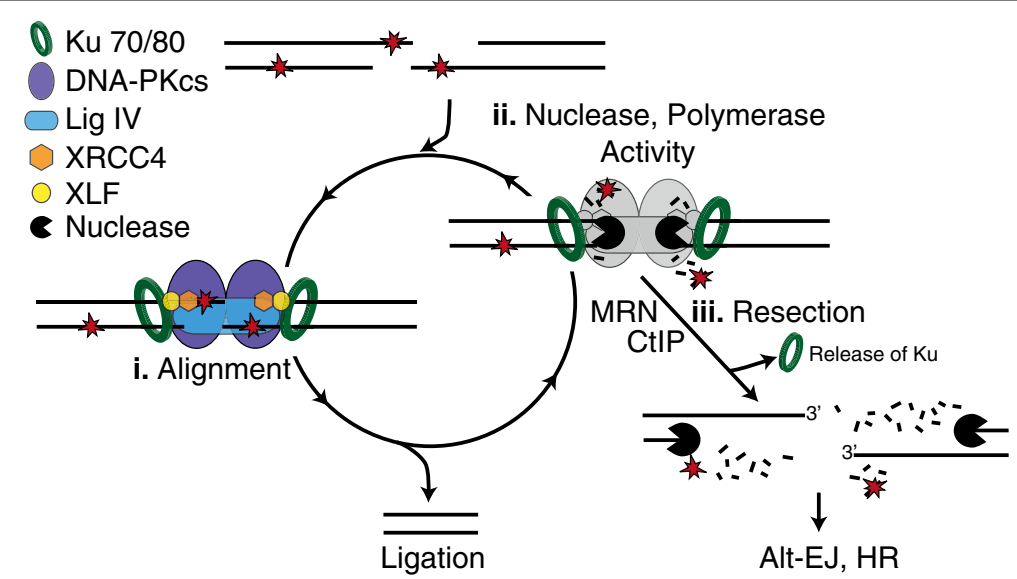

Figure 5 Trial and error. Ends can go through sequential rounds of end alignment (i) and processing (ii) (primarily nucleases; black Pac-man) until ligated. Alternatively, ends can be resected (iii) and Ku released, enabling resolution of ends by homologous recombination (HR) or alternative end-joining (Alt-EJ) pathways. 


\section{Tyrosyl DNA phosphodiesterases}

Topoisomerases (Top I, Top II) resolve DNA topological stress associated with replication and transcription. They employ a cleavage/ligation cycle with an intermediate step where a tyrosine in the topoisomerase is covalently linked to a strand break through $3^{\prime}$ or $5^{\prime}$ phosphate termini (Top I and top II, respectively) [62]. The cleavage/ ligation equilibrium can be altered (e.g. after treatment with topoisomerase poisons) such that cells accumulate strand breaks with termini adducted to a topoisomerase through their active site tyrosine [5]. If a type I topoisomerase aborts, the topoisomerase is adducted to a single strand break, $3^{\prime}$ phosphate terminus; if a type II topoisomerase aborts, the topoisomerase is adducted to DSB 5 phosphate termini. Adducted topoisomerases can be removed from DNA strand termini by reversal of the covalent intermediate, through the action of tyrosylDNA phosphodiesterases Tdp1 [63] and Tdp2 [64].

Tdp1's primary substrates are the 3'-phosphotyrosine adducts generated by aborted type I topoisomerase activity, either at SSBs, or DSBs generated after replication through unrepaired SSBs $[65,66]$. Epistasis analysis indicates Tdp1 activity on even the DSB-associated products is upstream of repair by HR in S. cerevisae [66]. However, Tdp 1 additionally has activity on other $3^{\prime}$ phosphate adducts including 3 '-phosphoglycolates [67-71] (Table 1), the most common class of nucleotide damage associated with ionizing radiation induced strand breaks. Tdp1 is required for resolution by NHEJ of substrates with $3^{\prime}$-phosphoglycolate termini in a cell extract model [47], and patients with Tdp1 mutations (Spinocerebellar ataxia with axonal neuropathy 1 ; SCAN-1) [72,73] are sensitive to radiomimetic drugs that can introduce strand breaks with 3 '-phosphoglycolate termini $[47,74]$. At the same time there are significant backup pathways active in cells [75], possibly explaining why SCAN1 cells are neither severely sensitive to ionizing radiation [71], nor possess obvious defects in rates of DSB repair after ionizing radiation [76].

Tdp2 (also termed TTRAP; TRAF and TNF receptorassociated protein, and EAPII; ETS1 associated protein II) is most active in removing tyrosines adducted to $5^{\prime}$ phosphates at DSB ends [64,77], a product of aborted type II topoisomerase action. Consistent with this specificity, Tdp2 is essential for resistance of chicken DT-40 cells to type II topoisomerase poisons (e.g. etoposide) [78]. Tdp2 could in principle participate in either HR or NHEJ pathways for DSB repair, and there are as yet no reported epistasis analyses or physical interactions specifically linking Tdp2 to either. Nevertheless, a role for Tdp2 uniquely within NHEJ seems most likely. Unlike Top I adducts, there is little use for "clean" removal of Top II adducts within the HR pathway, since the $5^{\prime}$ strand must anyway be extensively resected as a pre- requisite for the homology search step. Indeed, removal of the Top II-like Spo11 adduct at DSB intermediates during meiotic HR relies on the Mre11/Nbs1/CtIP complex; this latter pathway is apparently Tdp2 independent, as the excised Spo11 is still adducted to a short oligonucleotide [79].

\section{$\mathrm{Ku}$}

DSB with associated abasic sites, either $5^{\prime}$ terminal $\left(5^{\prime}\right.$ deoxyribose phosphate; $5^{\prime}$-dRP) or near-terminal (apurinic/apyrimidinic; AP), can be generated directly by ionizing radiation. However, they are probably more frequently associated with DSB products of aborted base excision repair, including the DSB intermediates in immunoglobulin class switch recombination [80,81]. Regardless of source, NHEJ cannot join such ends together both in vitro (whether or not XLF is present) [25-27,29] or in cells $[27,29]$ unless the abasic site is excised. Excision of these abasic sites is mediated both in vitro and in cells primarily by the Ku heterodimer which, in addition to its primary role in recognizing ends and recruiting other factors, is a $5^{\prime}$-dRP/AP lyase [27]. Notably, Ku's $5^{\prime}$ $\mathrm{dRP} / \mathrm{AP}$ activity is primarily restricted to substrates where incision is both necessary and sufficient to prepare ends for the ligation step [29]. Specifically, Ku is much less active on abasic sites near $3^{\prime}$ termini, where incision by a lyase would leave a ligation blocking $3^{\prime}-\alpha$, $\beta$-unsaturated aldehyde. $\mathrm{Ku}$ is similarly much less active when abasic sites near $5^{\prime}$ termini are significantly embedded in duplex DNA, a context where the abasic site no longer blocks the ligation step. The latter substrate specificity is essentially non-overlapping relative to abasic site metabolizing enzymes implicated in BER (AP endonuclease, pol $\beta$ ), whose activities are mostly restricted to sites with significant ( $>4 \mathrm{bp}$ ) flanking dsDNA $[26,27,29]$.

\section{Family X polymerases}

A variety of polymerases have been implicated in NHEJ (also reviewed in [82]), but the majority of evidence favors a primary role for several members of the mammalian family X polymerase: Pol $\lambda$, Pol $\mu$, and Terminal deoxynucleotidyl transferase (TdT). All three polymerases possess homologous $\mathrm{N}$-terminal BRCT (Breast cancer associated carboxy-terminal) domains [83] that promote formation of a complex including the polymerase, $\mathrm{Ku}$ and X4-LIV at DNA ends [84-90]. BRCT domains have no impact on intrinsic catalytic activity but are essential for the participation of the polymerases in NHEJ, emphasizing the importance of coupling their catalytic activities to a complex of aligned ends $[85,87,90]$. The three polymerases have distinct substrate requirements and activities, with decreasing dependence on template strand, in order Pol $\lambda>\operatorname{Pol} \mu>$ TdT [90]. All 
three have been clearly implicated in repair by NHEJ of intermediates in $\mathrm{V}(\mathrm{D}) \mathrm{J}$ recombination [91-94], with TdT's entirely template independent activity observed only during $\mathrm{V}(\mathrm{D}) \mathrm{J}$ recombination by virtue of its restricted expression [95]. The other two polymerases are expressed in all cell types and have overlapping activities [83,96], making it difficult to parse their relative contributions. In general, they fill in gaps present after alignment of broken ends (the gap typically a consequence of prior excision of damaged nucleotides by enzymes discussed above). The action of Pol $\mu$ and Pol $\lambda$ thus further extends parallels between NHEJ and BER/ SSBR, and indeed Pol $\lambda$ has roles in both [97-99], similar to APTX, PNKP and APLF.

\section{Trial and error}

NHEJ can use enzymes that specifically and precisely resolve many of the end structures expected to interfere with ligation of DSB ends. This means some fraction of NHEJ can proceed by an ordered, three-step strategy (excision, replacement, ligation; Figure 4) essentially equivalent to that used by base excision repair. However, such a strategy will not always suffice for DSBs. Some end structures do not appear to be readily resolved by the available enzymes (e.g. reduced abasic sites; $[27,29])$. Additionally, it is not yet clear how well NHEJ can identify the enzyme appropriate to a given context; this may be particularly challenging at ends associated with densely-clustered damage. A fraction of NHEJ could thus proceed by "trial and error". In this strategy, ends would be subject to sequential ligation attempts (Figure 5, step i, "trial") and end processing (Figure 5, step ii, "error"), with these steps repeated until a substrate for ligation is generated. We suggest that efficient resolution by this strategy implies a need for regulated transition between steps.

This strategy employs processing factors that are more likely to be endonucleases that target secondary structures (single stranded overhangs, flaps, hairpins) and exonucleases, including Artemis [100], MRN [101], Werner's syndrome protein [102], APLF [61], and Metnase [103]. Substrate specificities of these nucleases can be overlapping, and are generally less precisely targeted than the damage specific activities discussed above. Importantly, the latter characteristic allows them to aid in resolution of a wider variety of blocking lesions (more flexible), but the ensuing products are typically associated with greater deletion of DNA flanking the break site and are more heterogeneous. Initial overhang sequence complementarity will thus be reduced or lost, necessitating additional rounds of processing for ligation.

\section{Artemis}

Artemis has been associated with $5^{\prime}>3^{\prime}$ exonuclease activity, but can be primarily linked to NHEJ through an important role for its structure-specific endonuclease activity [100]. The latter is mediated by a metallo $\beta$ lactamase associated with $\underline{\text { CPSF }}$ Artemis $\underline{\mathrm{SNM}} 1$ PSO2 domain [104-106]. Nuclease activity is dependent on the additional presence of DNA-PKcs at ends [100], as well as DNA-PKcs autophosphorylation [107]. Artemis's C terminus is also phosphorylated by both DNA-PKcs and the related Ataxia Telangiectasia Mutated (ATM) kinase [106,108-112], and this may further help regulate Artemis activity. Most notably, Artemis is required for opening hairpins at broken ends. Such structures are critical intermediates in the assembly of antigen specific receptors by $\mathrm{V}(\mathrm{D}) \mathrm{J}$ recombination, consequently loss of Artemis function results in severe immunodeficiency $[100,113]$. Loss of Artemis also confers cellular sensitivity to IR [113-115], suggestive of a role for this nuclease in resolving complex end structures expected from IRinduced breaks. Consistent with this, Artemis generally cleaves at ssDNA/dsDNA transitions, and thus can remove extended ( $>4$ nucleotide) ssDNA overhangs and flaps $[100,109]$, as well as overhangs with ligation blocking nucleotide damage [116]. Notably, products of Artemis nuclease activity are heterogenous, with sites of cleavage often distributed over a 3-6 nucleotide range $[100,109,116,117]$. For example, Artemis, like Tdp1, can excise 3'-phosphoglycolate termini in vitro but Artemis typically deletes a variable number of nucleotides in addition to the $3^{\prime}$-phosphoglycolate residue [116]. Both the increased deletion and deletion heterogeneity associated with Artemis activity will more frequently necessitate additional rounds of processing before ends can be ligated, relative to the damage specific activities described in the previous section [87].

\section{Werners syndrome protein}

Werners syndrome is associated with progeria [118] and mild cellular sensitivity to ionizing radiation [119]. The Werners syndrome gene product (WRN) has both $3^{\prime}>5^{\prime}$ exonuclease and helicase activity [120-122], and associates with NHEJ core factors $\mathrm{Ku}[102,123]$ and X4-LIV [124]. WRN activity is further regulated by DNA-PKcs $[119,125]$, and can cooperate with these NHEJ factors to promote ligation in vitro after degradation of noncomplementary overhangs [124]. Notably, WRN can degrade through oxidative damage in the presence of $\mathrm{Ku}$ in some contexts $[126,127]$, possibly promoting NHEJ at ends where the density of break-associated damage is too high for damage specific resolutions.

\section{Mre11/Rad50/Nbs1}

The Mre11/Rad50/Nbs1 (MRN) complex (or Mre11/ Rad50/Xrs2 in S. cerevisae) is required for efficient sensing of double strand breaks and helps bridge broken ends together (reviewed in [128]). Similar to Artemis, 
MRN also has $3^{\prime}>5^{\prime}$ exonuclease and single strand specific endonuclease activities (including hairpin opening activity) $[101,129]$, but while MRN has an important role in mammalian NHEJ [130-132] this role is only partly reliant on MRN's nuclease activity [132]. Notably, MRN nuclease activity is essential for removal of Spo11 covalently adducted to $5^{\prime}$ termini (a substrate analogous to aborted Topoisomerase II complexes) [79,133]. However, activity of the MRN and CtIP complex on this substrate precedes a more processive resection of $5^{\prime}$ ends (reviewed in [134]) that primarily channels these breaks to repair by the homologous recombination pathway. Indeed, MRN/CtIP may perform this function whenever end structures cannot be resolved by any of the NHEJ strategies discussed (Figure 5 step iii), allowing these ends to be resolved instead by either alternate end joining or homologous recombination. Consistent with this idea, MRN's nuclease activity has been implicated in release of $\mathrm{Ku}$ from DNA ends [135], thereby precluding further futile NHEJ attempts.

\section{Concluding remarks: is it better to be lucky than good?}

Complex end structures are diverse, explaining why NHEJ employs three distinguishable strategies (Figure 2) and a host of different processing activities (Table 1). Moreover, processing activities have varying degrees of substrate specificity, allowing NHEJ to balance precision with flexibility during end processing. When processing is required, these steps are appropriately ordered and coupled to the ligation step within a multiprotein machine. NHEJ is therefore indispensible for efficient resolution of complex end structures.

Ideally, NHEJ chooses a resolution strategy and processing factor in a manner that optimizes the efficiency and fidelity of product. With respect to strategy, there may be a means for sensing the extent of damage first and specifically choosing the appropriate strategy (Figure 2). Alternatively, strategies may be employed hierarchically, starting with damage tolerance, followed by damage specific end cleaning, followed by trial and error. Additionally, the choice of processing factor may be determined only by its affinity for a specific substrate, or might additionally be regulated by access to its substrate.

Accumulating evidence implicates DNA-PKcs kinase activity as the primary factor that could determine both choice of strategy and processing factor. DNA-PKcs kinase activity is dependent on end context, both in terms of whether a pair of ends can be aligned together $[136,137]$, but also as a reflection of differences in end structure [138-140]. Additionally (as noted above), DNA-PKcs-mediated phosphorylation of Artemis [107-112], PNKP [51,52], Tdp1 [65], WRN [119,125], and XLF-X4-LIV [31] can affect the activity of these proteins. However, DNA-PKcs itself is probably the most relevant target (i.e., autophosphorylation), as there are in excess of 30 different sites (reviewed in [141]) that together may be sufficient for a "code," where phosphorylation of different patches has distinguishable effects on end access [142-144].

Events in the resolution of complex ends by NHEJ can thus be, to some extent, left to chance, but can also be precisely scripted. So, is it better to be lucky than good? Why not both?

\section{Competing interests}

The authors declare no competing interests.

\section{Authors' contributions}

NTS, CAW, and DAR wrote the manuscript, and N.T.S. assembled the figures. All authors read and approved the final manuscript.

\section{Acknowledgements}

We thank the members of the Ramsden laboratory for their helpful discussion. This work was supported by $\mathrm{NIH} \mathrm{NCl}$ grants CA 84442 and CA 97096 to D.A.R.

Received: 22 October 2012 Accepted: 16 December 2012

Published: 31 December 2012

References

1. Hiom K: Coping with DNA double strand breaks. DNA Repair 2010, 9:1256-1263.

2. Burkhalter MD, Roberts SA, Havener JM, Ramsden DA: Activity of ribonucleotide reductase helps determine how cells repair DNA double strand breaks. DNA Repair 2009, 8:1258-1263.

3. Ward JF: The complexity of DNA damage: relevance to biological consequences. Int J Radiat Biol 1994, 66:427-432.

4. Goodhead DT: Initial events in the cellular effects of ionizing radiations: clustered damage in DNA. Int J Radiat Biol 1994, 65:7-17.

5. Nitiss JL: Targeting DNA topoisomerase II in cancer chemotherapy. Nat Rev Cancer 2009, 9:338-350.

6. Lieber MR: The mechanism of double-strand DNA break repair by the non-homologous DNA end-joining pathway. Annu Rev Biochem 2010, 79:181-211.

7. Lukas J, Lukas C, Bartek J: More than just a focus: the chromatin response to DNA damage and its role in genome integrity maintenance. Nat Cell Biol 2011, 13:1161-1169.

8. Ellenberger T, Tomkinson AE: Eukaryotic DNA ligases: structural and functional insights. Annu Rev Biochem 2008, 77:313-338.

9. Gu J, Lu H, Tippin B, Shimazaki N, Goodman MF, Lieber MR: XRCC4:DNA ligase IV can ligate incompatible DNA ends and can ligate across gaps. EMBO J 2007, 26:1-14

10. Wang Y, Lamarche BJ, Tsai MD: Human DNA ligase IV and the ligase IV/ XRCC4 complex: analysis of nick ligation fidelity. Biochemistry 2007, 46:4962-4976

11. Gu J, Lu H, Tsai AG, Schwarz K, Lieber MR: Single-stranded DNA ligation and XLF-stimulated incompatible DNA end ligation by the XRCC4-DNA ligase IV complex: influence of terminal DNA sequence. Nucleic Acids Res 2007, 35:5755-5762

12. Tsai CJ, Kim SA, Chu G: Cernunnos/XLF promotes the ligation of mismatched and noncohesive DNA ends. Proc Natl Acad Sci USA 2007, 104:7851-7856.

13. Ahnesorg $P$, Smith $P$, Jackson SP: XLF interacts with the XRCC4-DNA ligase IV complex to promote DNA non-homologous end-joining. Cell 2006, 124:301-313.

14. Andres SN, Modesti M, Tsai CJ, Chu G, Junop MS: Crystal structure of human XLF: a twist in non-homologous DNA end-joining. Mol Cell 2007, 28:1093-1101.

15. Hentges PP, Ahnesorg PP, Pitcher RSR, Bruce CKC, Kysela BB, Green AJA, Bianchi JJ, Wilson TET, Jackson SPS, Doherty AJA: Evolutionary and 
functional conservation of the DNA non-homologous end-joining protein, XLF/Cernunnos. J Biol Chem 2006, 281:37517-37526.

16. Li Y, Chirgadze DY, Bolanos-Garcia VM, Sibanda BL, Davies OR, Ahnesorg P, Jackson SP, Blundell TL: Crystal structure of human XLF/Cernunnos reveals unexpected differences from XRCC4 with implications for NHEJ. EMBO J 2007, 27:290-300.

17. Lu H, Pannicke U, Schwarz K, Lieber MR: Length-dependent binding of human XLF to DNA and stimulation of XRCC4.DNA ligase IV activity. J Biol Chem 2007, 282:11155-11162.

18. Sulek $M$, Yarrington R, McGibbon G, Boeke JD, Junop M: A critical role for the C-terminus of Nej1 protein in Lif1p association, DNA binding and non-homologous end-joining. DNA Repair 2007, 6:1805-1818.

19. Andres SN, Vergnes A, Ristic D, Wyman C, Modesti M, Junop M: A human XRCC4-XLF complex bridges DNA. Nucleic Acids Res 2012, 40:1868-1878.

20. Hammel M, Rey M, Yu Y, Mani RS, Classen S, Liu M, Pique ME, Fang S, Mahaney BL, Weinfeld M, et al: XRCC4 protein interactions with XRCC4like factor (XLF) create an extended grooved scaffold for DNA ligation and double strand break repair. J Biol Chem 2011, 286:32638-32650.

21. Hammel M, Yu Y, Fang S, Lees-Miller SP, Tainer JA: XLF regulates filament architecture of the XRCC4. ligase IV complex. Structure/Folding and Design 2010, 18:1431-1442.

22. Ochi T, Wu Q, Chirgadze DY, Grossmann JG, Bolanos-Garcia VM, Blundell TL: Structural insights into the role of domain flexibility in human DNA ligase IV. Structure 2012, 20:1212-1222.

23. Ropars V, Drevet $P$, Legrand $P$, Baconnais $S$, Amram J, Faure G, Márquez JA, Piétrement O, Guerois R, Callebaut I: Structural characterization of filaments formed by human Xrcc4-Cernunnos/XLF complex involved in non-homologous DNA end-joining. Proc Natl Acad Sci USA 2011, 108:12663-12668

24. Chen S, Inamdar KV, Pfeiffer P, Feldmann E, Hannah MF, Yu Y, Lee JW, Zhou T, Lees-Miller SP, Povirk LF: Accurate in vitro end joining of a DNA double strand break with partially cohesive 3'-overhangs and 3'-phosphoglycolate termini. J Biol 2001, 276:24323-24330.

25. Datta K, Purkayastha S, Neumann RD, Pastwa E, Winters TA: Base damage immediately upstream from double-strand break ends is a more severe impediment to non-homologous end joining than blocked 3'-termini. Radiat Res 2010, 175:97-112.

26. Dobbs TA, Palmer P, Maniou Z, Lomax ME, O'Neill P: Interplay of two major repair pathways in the processing of complex double-strand DNA breaks. DNA Repair 2008, 7:1372-1383.

27. Roberts SA, Strande N, Burkhalter MD, Strom C, Havener JM, Hasty P, Ramsden DA: $\mathrm{Ku}$ is a $5^{\prime}$-dRP/AP lyase that excises nucleotide damage near broken ends. Nature 2010, 464:1214-1217.

28. Roberts SAS, Ramsden DAD: Loading of the non-homologous end joining factor, Ku, on protein-occluded DNA ends. J Biol Chem 2007, 282:10605-10613.

29. Strande N, Roberts SA, Oh S, Hendrickson EA, Ramsden DA: Specificity of the dRP/AP lyase of Ku promotes non-homologous end joining (NHEJ) fidelity at damaged ends. J Biol Chem 2012, 287:13686-13693.

30. Sears CR, Turchi JJ: Complex cisplatin-double strand break (DSB) lesions directly impair cellular non-homologous end-joining (NHEJ) independent of downstream damage response (DDR) pathways. J Biol Chem 2012, 287:24263-24272

31. Roy $S$, Andres SN, Vergnes A, Neal JA, Xu Y, Yu Y, Lees-Miller SP, Junop M, Modesti M, Meek K: XRCC4's interaction with XLF is required for coding (but not signal) end joining. Nucleic Acids Res 2012, 40:1684-1694

32. Gulston M: Processing of clustered DNA damage generates additional double-strand breaks in mammalian cells post-irradiation. Nucleic Acids Res 2004, 32:1602-1609.

33. Ma W, Westmoreland JW, Gordenin DA, Resnick MA: Alkylation base damage is converted into repairable double-strand breaks and complex intermediates in G2 cells lacking AP endonuclease. PLoS Genet 2011, 7:e1002059.

34. Malyarchuk S, Castore R, Harrison L: DNA repair of clustered lesions in mammalian cells: involvement of non-homologous end-joining. Nucleic Acids Res 2008, 36:4872-4882.

35. Malyarchuk S, Castore R, Harrison L: Apex1 can cleave complex clustered DNA lesions in cells. DNA Repair 2009, 8:1343-1354.

36. Yang N, Galick H, Wallace SS: Attempted base excision repair of ionizing radiation damage in human lymphoblastoid cells produces lethal and mutagenic double strand breaks. DNA Repair 2004, 3:1323-1334.
37. Caldecott KW: Single-strand break repair and genetic disease. Nat Rev Genet 2008, 9:619-631.

38. Koch CA, Agyei R, Galicia S, Metalnikov P, O' Donnell P, Starostine A, Weinfeld $M$, Durocher D: Xrcc 4 physically links DNA end processing by polynucleotide kinase to DNA ligation by DNA ligase IV. EMBO J 2004, 23:3874-3885.

39. Loizou JI, El-Khamisy SF, Zlatanou A, Moore DJ, Chan DW, Qin J, Sarno S, Meggio F, Pinna LA, Caldecott KW: The protein kinase CK2 facilitates repair of chromosomal DNA single-strand breaks. Cell 2004, 117:17-28,

40. Ahel I, Rass U, El-Khamisy SF, Katyal S, Clements PM, McKinnon PJ, Caldecott KW, West SC: The neurodegenerative disease protein aprataxin resolves abortive DNA ligation intermediates. Nature 2006, 443:713-716.

41. Date H, Onodera O, Tanaka H, Iwabuchi K, Uekawa K, Igarashi S, Koike R, Hiroi T, Yuasa T, Awaya Y, et al: Early-onset ataxia with ocular motor apraxia and hypoalbuminemia is caused by mutations in a new HIT superfamily gene. Nat Genet 2001, 29:184-188.

42. Moreira MCM, Barbot CC, Tachi NN, Kozuka NN, Uchida EE, Gibson TT, Mendonça PP, Costa MM, Barros JJ, Yanagisawa TT, et al: The gene mutated in ataxia-ocular apraxia 1 encodes the new HIT/Zn-finger protein aprataxin. Nat Genet 2001, 29:189-193.

43. Clements PM, Breslin C, Deeks ED, Byrd PJ, Ju L, Bieganowski P, Brenner C, Moreira M-C, Taylor AMR, Caldecott KW: The ataxia-oculomotor apraxia 1 gene product has a role distinct from ATM and interacts with the DNA strand break repair proteins XRCC1 and XRCC4. DNA Repair 2004, 3:1493-1502.

44. El-Khamisy SF, Katyal S, Patel P, Ju L, McKinnon PJ, Caldecott KW: Synergistic decrease of DNA single-strand break repair rates in mouse neural cells lacking both Tdp1 and aprataxin. DNA Repair 2009, 8:760-766.

45. Jilani A, Ramotar D, Slack C, Ong C, Yang XM, Scherer SW, Lasko DD: Molecular cloning of the human gene, PNKP, encoding a polynucleotide kinase 3/-phosphatase and evidence for its role in repair of DNA strand breaks caused by oxidative damage. J Biol Chem 1999, 274:24176-24186.

46. Weinfeld M, Mani RS, Abdou I, Aceytuno RD, Glover JNM: Tidying up loose ends: the role of polynucleotide kinase/phosphatase in DNA strand break repair. Trends Biochem Sci 2011, 36:262-271.

47. Zhou TT, Akopiants KK, Mohapatra SS, Lin P-SP, Valerie KK, Ramsden DAD, Lees-Miller SPS, Povirk LFL: Tyrosyl-DNA phosphodiesterase and the repair of 3'-phosphoglycolate-terminated DNA double-strand breaks. DNA Repair 2009, 8:901-911.

48. Shen J, Gilmore EC, Marshall CA, Haddadin M, Reynolds JJ, Eyaid W, Bodell A, Barry B, Gleason D, Allen K, et al: Mutations in PNKP cause microcephaly, seizures and defects in DNA repair. Nat Genet 2010, 42:245-249.

49. Rasouli-Nia A, Karimi-Busheri F, Weinfeld M: Stable down-regulation of human polynucleotide kinase enhances spontaneous mutation frequency and sensitizes cells to genotoxic agents. Proc Natl Acad Sci USA 2004, 101:6905-6910.

50. Chappell C, Hanakahi LA, Karimi-Busheri F, Weinfeld M, West SC: Involvement of human polynucleotide kinase in double-strand break repair by non-homologous end joining. EMBO J 2002, 21:2827-2832.

51. Segal-Raz H, Mass G, Baranes-Bachar K, Lerenthal Y, Wang S-Y, Chung YM, Ziv-Lehrman S, Ström CE, Helleday T, Hu MC-T, et al: ATM-mediated phosphorylation of polynucleotide kinase/phosphatase is required for effective DNA double-strand break repair. EMBO Rep 2011, 12:713-719.

52. Zolner AE, Abdou I, Ye R, Mani RS, Fanta M, Yu Y, Douglas P, Tahbaz N, Fang S, Dobbs T, et al: Phosphorylation of polynucleotide kinase/ phosphatase by DNA-dependent protein kinase and ataxia-telangiectasia mutated regulates its association with sites of DNA damage. Nucleic Acids Res 2011, 39:9224-9237.

53. Ahel I, Ahel D, Matsusaka T, Clark AJ, Pines J, Boulton SJ, West SC: Poly(ADP-ribose)-binding zinc finger motifs in DNA repair/checkpoint proteins. Nature 2008, 451:81-85.

54. Bekker-Jensen SS, Fugger KK, Danielsen JRJ, Gromova II, Sehested MM, Celis JJ, Bartek JJ, Lukas JJ, Mailand NN: Human Xip1 (C2orf13) is a novel regulator of cellular responses to DNA strand breaks. J Biol Chem 2007, 282:19638-19643.

55. Iles N, Rulten S, El Khamisy SF, Caldecott KW: APLF (C2orf13) is a novel human protein involved in the cellular response to chromosomal DNA strand breaks. Mol Cell Biol 2007, 27:3793-3803.

56. Kanno S-iS, Kuzuoka HH, Sasao SS, Hong ZZ, Lan LL, Nakajima SS, Yasui AA: A novel human AP endonuclease with conserved zinc-finger-like motifs involved in DNA strand break responses. EMBO J 2007, 26:2094-2103.

57. Macrae CJ, McCulloch RD, Ylanko J, Durocher D, Koch CA: APLF (C2orf13) facilitates non-homologous end-joining and undergoes ATM-dependent 
hyperphosphorylation following ionizing radiation. DNA Repair 2008, 7:292-302.

58. Rulten SL, Fisher AEO, Robert I, Zuma MC, Rouleau M, Ju L, Poirier G, Reina-San-Martin B, Caldecott KW: PARP-3 and APLF function together to accelerate non-homologous end-joining. Mol Cell 2011, 41:33-45.

59. Mehrotra PV, Ahel D, Ryan DP, Weston R, Wiechens N, Kraehenbuehl R, Owen-Hughes T, Ahel I: DNA repair factor APLF is a histone chaperone. Mol Cell 2011, 41:46-55.

60. Kysela B, Doherty AJ, Chovanec M, Stiff T, Ameer-Beg SM, Vojnovic B, Girard P-M, Jeggo PA: Ku stimulation of DNA ligase IV-dependent ligation requires inward movement along the DNA molecule. J Biol Chem 2003, 278:22466-22474.

61. Li S, Kanno S-i, Watanabe R, Ogiwara H, Kohno T, Watanabe G, Yasui A, Lieber MR: Polynucleotide kinase and aprataxin-like forkhead-associated protein (PALF) acts as both a single-stranded DNA endonuclease and a single-stranded DNA 3/ exonuclease and can participate in DNA end joining in a biochemical system. J Biol Chem 2011, 286:36368-36377.

62. Wang JC: Cellular roles of DNA topoisomerases: a molecular perspective. Nat Rev Mol Cell Biol 2002, 3:430-440.

63. Yang SWS, Burgin ABA, Huizenga BNB, Robertson CAC, Yao KCK, Nash HAH: A eukaryotic enzyme that can disjoin dead-end covalent complexes between DNA and type I topoisomerases. Proc Natl Acad Sci USA 1996 93:11534-11539.

64. Ledesma FC, El-Khamisy SF, Zuma MC, Osborn K, Caldecott KW: A human 5/-tyrosyl DNA phosphodiesterase that repairs topoisomerase-mediated DNA damage. Nature 2009, 461:674-678.

65. Das BBB, Antony SS, Gupta SS, Dexheimer TST, Redon CEC, Garfield SS, Shiloh YY, Pommier YY: Optimal function of the DNA repair enzyme TDP1 requires its phosphorylation by ATM and/or DNA-PK. EMBO J 2009, 28:3667-3680.

66. Pouliot JJJ, Robertson CAC, Nash HAH: Pathways for repair of topoisomerase I covalent complexes in Saccharomyces cerevisiae. Genes Cells 2001, 6:677-687.

67. Inamdar KV, Pouliot JJ, Zhou T, Lees-Miller SP, Rasouli-Nia A, Povirk LF: Conversion of phosphoglycolate to phosphate termini on 3/ overhangs of DNA double strand breaks by the human tyrosyl-DNA phosphodiesterase hTdp1. J Biol Chem 2002, 277:27162-27168.

68. Interthal HH, Chen HJH, Champoux JJJ: Human Tdp1 cleaves a broad spectrum of substrates, including phosphoamide linkages. J Biol Chem 2005, 280:36518-36528.

69. Lebedeva NA, Rechkunova NI, Lavrik Ol: AP-site cleavage activity of tyrosyl-DNA phosphodiesterase 1. FEBS Lett 2011, 585:683-686.

70. Lebedeva NAN, Rechkunova NIN, El-Khamisy SFS, Lavrik OIO: Tyrosyl-DNA phosphodiesterase 1 initiates repair of apurinic/apyrimidinic sites. Biochimie 2012, 94:1749-1753.

71. Zhou T, Lee JW, Tatavarthi H, Lupski JR, Valerie K, Povirk LF: Deficiency in 3/-phosphoglycolate processing in human cells with a hereditary mutation in tyrosyl-DNA phosphodiesterase (TDP1). Nucleic Acids Res 2005, 33:289-297.

72. El-Khamisy SF, Saifi GM, Weinfeld M, Johansson F, Helleday T, Lupski JR, Caldecott KW: Defective DNA single-strand break repair in spinocerebellar ataxia with axonal neuropathy-1. Nature 2005, 434:108-113.

73. Takashima H, Boerkoel CF, John J, Saifi GM, Salih MAM, Armstrong D, Mao Y, Quiocho FA, Roa BB, Nakagawa M, et al: Mutation of TDP1, encoding a topoisomerase I-dependent DNA damage repair enzyme, in spinocerebellar ataxia with axonal neuropathy. Nat Genet 2002, 32:267-272.

74. Hirano R, Interthal H, Huang C, Nakamura T, Deguchi K, Choi K, Bhattacharjee MB, Arimura K, Umehara F, Izumo S, et al: Spinocerebellar ataxia with axonal neuropathy: consequence of a Tdp1 recessive neomorphic mutation? EMBO J 2007, 26:4732-4743.

75. Povirk LF, Zhou T, Zhou R, Cowan MJ, Yannone SM: Processing of 3'phosphoglycolate-terminated DNA double strand breaks by artemis nuclease. J Biol Chem 2006, 282:3547-3558.

76. El-Khamisy SF, Hartsuiker E, Caldecott KW: TDP1 facilitates repair of ionizing radiation-induced DNA single-strand breaks. DNA Repair 2007, 6:1485-1495.

77. Gao R, Huang S-YN, Marchand C, Pommier Y: Biochemical characterization of human tyrosyl-DNA phosphodiesterase 2 (TDP2/TTRAP): a Mg2+/Mn2 +-dependent phosphodiesterase specific for the repair of topoisomerase cleavage complexes. J Biol Chem 2012, 287:30842-30852.

78. Zeng Z, Cortés-Ledesma F, El-Khamisy SF, Caldecott KW: TDP2/TTRAP is the major 5'-tyrosyl DNA phosphodiesterase activity in vertebrate cells and is critical for cellular resistance to topoisomerase II-induced DNA damage. J Biol Chem 2011, 286:403-409.

79. Neale MJ, Pan J, Keeney S: Endonucleolytic processing of covalent protein-linked DNA double-strand breaks. Nature 2005, 436:1053-1057.

80. Di Noia JM, Williams GT, Chan DT, Buerstedde JM, Baldwin GS, Neuberger MS: Dependence of antibody gene diversification on uracil excision. $J$ Exp Med 2007, 204:3209-3219.

81. Rada C, Di Noia JM, Neuberger MS: Mismatch recognition and uracil excision provide complementary paths to both Ig switching and the A/T-focused phase of somatic mutation. Mol Cell 2004, 16:163-171.

82. Ramsden DA: Polymerases in non-homologous end joining: building a bridge over broken chromosomes. Antioxid Redox Signal 2011, 14:2509-2519.

83. Aoufouchi S, Flatter E, Dahan A, Faili A, Bertocci B, Storck S, Delbos F, Cocea L, Gupta N, Weill JC, Reynaud CA: Two novel human and mouse DNA polymerases of the polX family. Nucleic Acids Res 2000, 28:3684-3693.

84. DeRose EF, Clarkson MW, Gilmore SA, Galban CJ, Tripathy A, Havener JM, Mueller GA, Ramsden DA, London RE, Lee AL: Solution structure of polymerase mu's BRCT Domain reveals an element essential for its role in non-homologous end joining. Biochemistry 2007, 46:12100-12110.

85. Fan $\mathrm{W}, \mathrm{Wu} X$ : DNA polymerase lambda can elongate on DNA substrates mimicking non-homologous end joining and interact with XRCC4-ligase IV complex. Biochem Biophys Res Commun 2004, 323:1328-1333.

86. Lee JW, Blanco L, Zhou T, Garcia-Diaz M, Bebenek K, Kunkel TA, Wang Z Povirk LF: Implication of DNA polymerase lambda in alignment-based gap filling for non-homologous DNA end joining in human nuclear extracts. J Biol Chem 2004, 279:805-811.

87. Ma Y, Lu H, Tippin B, Goodman MF, Shimazaki N, Koiwai O, Hsieh C-L, Schwarz K, Lieber MR: A biochemically defined system for mammalian non-homologous DNA end joining. Mol Cell 2004, 16:701-713.

88. Mahajan KN, Nick McElhinny SA, Mitchell BS, Ramsden DA: Association of DNA polymerase $\mathrm{mu}$ (pol $\mathrm{mu}$ ) with $\mathrm{Ku}$ and ligase IV: role for pol $\mathrm{mu}$ in end-joining double-strand break repair. Mol Cell Biol 2002, 22:5194-5202

89. Mueller GA, Moon AF, Derose EF, Havener JM, Ramsden DA, Pedersen LC, London RE: A comparison of BRCT domains involved in non-homologous end-joining: introducing the solution structure of the BRCT domain of polymerase lambda. DNA Repair 2008, 7:1340-1351.

90. Nick McEhinny SA, Havener JM, Garcia-Diaz M, Juarez R, Bebenek K, Kee BL, Blanco L, Kunkel TA, Ramsden DA: A gradient of template dependence defines distinct biological roles for family $\mathrm{X}$ polymerases in non-homologous end joining. Mol Cell 2005, 19:357-366.

91. Bertocci B, De Smet A, Berek C, Weill JC, Reynaud CA: Immunoglobulin kappa light chain gene rearrangement is impaired in mice deficient for DNA polymerase mu. Immunity 2003, 19:203-211.

92. Bertocci B, De Smet A, Weill JC, Reynaud CA: Nonoverlapping functions of DNA polymerases $\mathrm{mu}$, lambda, and terminal deoxynucleotidyltransferase during immunoglobulin V(D)J recombination in vivo. Immunity 2006, 25:31-41.

93. Gilfillan S, Dierich A, Lemeur M, Benoist C, Mathis D: Mice lacking TdT: mature animals with an immature lymphocyte repertoire. Science 1993, 261:1175-1178.

94. Komori T, Okada A, Stewart V, Alt FW: Lack of N regions in antigen receptor variable region genes of TdT-deficient lymphocytes. Science 1993, 261:1171-1175.

95. Benedict CL, Gilfillan S, Thai TH, Kearney JF: Terminal deoxynucleotidyl transferase and repertoire development. Immunol Rev 2000, 175:150-157.

96. Dominguez O, Ruiz JF, de Lera Lain T, Garcia-Diaz M, Gonzalez MA, Kirchhoff T, Martinez AC, Bernad A, Blanco L: DNA polymerase mu (Pol $\mathrm{mu}$ ), homologous to TdT, could act as a DNA mutator in eukaryotic cells. EMBO J 2000, 19:1731-1742.

97. Braithwaite EK, Kedar PS, Stumpo DJ, Bertocci B, Freedman JH, Samson LD, Wilson SH: DNA polymerases beta and lambda mediate overlapping and independent roles in base excision repair in mouse embryonic fibroblasts. PLoS One 2010, 5:e12229.

98. Braithwaite EK, Prasad R, Shock DD, Hou EW, Beard WA, Wilson SH: DNA polymerase lambda mediates a back-up base excision repair activity in extracts of mouse embryonic fibroblasts. J Biol Chem 2005, 280:18469-18475.

99. Tano K, Nakamura J, Asagoshi K, Arakawa H, Sonoda E, Braithwaite EK, Prasad R, Buerstedde JM, Takeda S, Watanabe M, Wilson SH: Interplay between DNA polymerases beta and lambda in repair of oxidation DNA damage in chicken DT40 cells. DNA Repair 2007, 6:869-875. 
100. Ma Y, Pannicke U, Schwarz K, Lieber MR: Hairpin opening and overhang processing by an Artemis/DNA-dependent protein kinase complex in non-homologous end joining and V(D)J recombination. Cell 2002, 108:781-794.

101. Paull T, Gellert M: The $3^{\prime}$ to $5^{\prime}$ exonuclease activity of Mre 11 facilitates repair of DNA double-strand breaks. Mol Cell 1998, 1:969.

102. Cooper MP, Machwe A, Orren DK, Brosh RM, Ramsden D, Bohr VA: Ku complex interacts with and stimulates the Werner protein. Genes \&amp; Development 2000, 14:907-912.

103. Beck BD, Lee S-S, Williamson E, Hromas RA, Lee S-H: Biochemical characterization of metnase's endonuclease activity and its role in NHEJ repair. Biochemistry 2011, 50:4360-4370.

104. Callebaut I, Moshous D, Mornon JP, de Villartay JP: Metallo-beta-lactamase fold within nucleic acids processing enzymes: the beta-CASP family. Nucleic Acids Res 2002, 30:3592-3601.

105. Pannicke U, Ma Y, Hopfner K-P, Niewolik D, Lieber MR, Schwarz K: Functional and biochemical dissection of the structure-specific nuclease ARTEMIS. EMBO J 2004, 23:1987-1997.

106. Poinsignon CC, Moshous DD, Callebaut II, de Chasseval RR, Villey II, de Villartay J-PJ: The metallo-beta-lactamase/beta-CASP domain of Artemis constitutes the catalytic core for V(D)J recombination. J Exp Med 2004, 199:315-321.

107. Goodarzi AA, Yu Y, Riballo E, Douglas P, Walker SA, Ye R, Harer C, Marchetti C, Morrice N, Jeggo PA, Lees-Miller SP: DNA-PK autophosphorylation facilitates artemis endonuclease activity. EMBO J 2006, 25:3880-3889

108. Chen L, Morio T, Minegishi Y, Nakada S, Nagasawa M, Komatsu K, Chessa L, Villa A, Lecis D, Delia D, Mizutani S: Ataxia-telangiectasia-mutated dependent phosphorylation of artemis in response to DNA damage. Cancer Sci 2005, 96:134-141.

109. Ma Y, Schwarz K, Lieber MR: The artemis: DNA-PKcs endonuclease cleaves DNA loops, flaps, and gaps. DNA Repair 2005, 4:845-851.

110. Riballo E, Kühne M, Rief N, Doherty A, Smith GCM, Recio M-J, Reis C, Dahm K, Fricke A, Krempler A, et al: A pathway of double-strand break rejoining dependent upon ATM, artemis, and proteins locating to gamma- $\mathrm{H} 2 \mathrm{AX}$ foci. Mol Cell 2004, 16:715-724.

111. Wang J, Pluth JM, Cooper PK, Cowan MJ, Chen DJ, Yannone SM: Artemis deficiency confers a DNA double-strand break repair defect and Artemis phosphorylation status is altered by DNA damage and cell cycle progression. DNA Repair 2005, 4:556-570.

112. Zhang X, Succi J, Feng Z, Prithivirajsingh S, Story MD, Legerski RJ: Artemis is a phosphorylation target of ATM and ATR and is involved in the G2/M DNA damage checkpoint response. Mol Cell Biol 2004, 24:9207-9220.

113. Moshous DD, Callebaut II, de Chasseval RR, Corneo BB, Cavazzana-Calvo MM, Le Deist FF, Tezcan II, Sanal OO, Bertrand YY, Philippe NN, et al: Artemis, a novel DNA double-strand break repair/V(D)J recombination protein, is mutated in human severe combined immune deficiency. Cell 2001, 105:177-186.

114. Nicolas N, Moshous D, Cavazzana-Calvo M, Papadopoulo D, de Chasseval R, Le Deist F, Fischer A, de Villartay J-P: A human severe combined immunodeficiency (SCID) condition with increased sensitivity to ionizing radiations and impaired $\mathrm{V}(\mathrm{D}) \mathrm{J}$ rearrangements defines a new DNA recombination/repair deficiency. J Exp Med 1998, 188:627-634.

115. Rooney S, Sekiguchi J, Zhu C, Cheng HL, Manis J, Whitlow S, DeVido J, Foy D, Chaudhuri J, Lombard D, Alt FW: Leaky Scid phenotype associated with defective $V(D) J$ coding end processing in artemis-deficient mice. Mol Cell 2002, 10:1379-1390.

116. Yannone SM, Khan IS, Zhou RZ, Zhou T, Valerie K, Povirk LF: Coordinate $5^{\prime}$ and $3^{\prime}$ endonucleolytic trimming of terminally blocked blunt DNA double-strand break ends by Artemis nuclease and DNA-dependent protein kinase. Nucleic Acids Res 2008, 36:3354-3365.

117. Lu H, Schwarz K, Lieber MR: Extent to which hairpin opening by the artemis:DNA-PKcs complex can contribute to junctional diversity in V(D)J recombination. Nucleic Acids Res 2007, 35:6917-6923.

118. Epstein CJ, Martin GM, Motulsky AG: Werner's syndrome; caricature of aging. A genetic model for the study of degenerative diseases. Trans Assoc Am Physicians 1965, 78:73-81.
119. Yannone SM, Roy S, Chan DW, Murphy MB, Huang S, Campisi J, Chen DJ: Werner syndrome protein is regulated and phosphorylated by DNAdependent protein kinase. J Biol Chem 2001, 276:38242-38248.

120. Gray MD, Shen JC, Kamath-Loeb AS, Blank A, Sopher BL, Martin GM, Oshima J, Loeb LA: The Werner syndrome protein is a DNA helicase. Nat Genet 1997, 17:100-103.

121. Huang SS, Li BB, Gray MDM, Oshima JJ, Mian ISI, Campisi JJ: The premature ageing syndrome protein, WRN, is a $3^{\prime}->5^{\prime}$ exonuclease. Nat Genet 1998 , 20:114-116.

122. Kamath-Loeb ASA, Shen JCJ, Loeb LAL, Fry MM: Werner syndrome protein. II. Characterization of the integral $3^{\prime} \rightarrow 5^{\prime}$ DNA exonuclease. J Biol Chem 1998, 273:34145-34150.

123. Li B, Comai L: Functional interaction between $\mathrm{Ku}$ and the werner syndrome protein in DNA end processing. J Biol Chem 2000, 275:28349-28352.

124. Kusumoto R, Dawut L, Marchetti C, Wan Lee J, Vindigni A, Ramsden D, Bohr VA: Werner protein cooperates with the XRCC4-DNA ligase IV complex in end-processing. Biochemistry 2008, 47:7548-7556.

125. Karmakar P, Piotrowski J, Brosh RM, Sommers JA, Miller SPL, Cheng W-H, Snowden CM, Ramsden DA, Bohr VA: Werner protein is a target of DNAdependent protein kinase in vivo and in vitro, and its catalytic activities are regulated by phosphorylation. J Biol Chem 2002 277:18291-18302.

126. Bukowy Z, Harrigan JA, Ramsden DA, Tudek B, Bohr VA, Stevnsner T: WRN Exonuclease activity is blocked by specific oxidatively induced base lesions positioned in either DNA strand. Nucleic Acids Res 2008, 36:4975-4987

127. Orren DK, Machwe A, Karmakar P, Piotrowski J, Cooper MP, Bohr VA: A functional interaction of Ku with Werner exonuclease facilitates digestion of damaged DNA. Nucleic Acids Res 2001, 29:1926-1934.

128. Stracker TH, Petrini JHJ: The MRE11 complex: starting from the ends. Nat Rev Mol Cell Biol 2011, 12:90-103.

129. Trujillo KM, Sung P: DNA structure-specific nuclease activities in the saccharomyces cerevisiae Rad50.Mre11 complex. J Biol Chem 2001, 276:35458-35464.

130. Xie A, Kwok A, Scully R: Role of mammalian Mre11 in classical and alternative non-homologous end joining. Nat Struct Mol Biol 2009, 16:814-818.

131. Rass E, Grabarz A, Plo I, Gautier J, Bertrand P, Lopez BS: Role of Mre11 in chromosomal non-homologous end joining in mammalian cells. Nat Struct Mol Biol 2009, 16:819-824.

132. Dinkelmann M, Spehalski E, Stoneham T, Buis J, Wu Y, Sekiguchi JM, Ferguson DO: Multiple functions of MRN in end-joining pathways during isotype class switching. Nat Struct Mol Biol 2009, 16:808-813.

133. Keeney S: Mechanism and control of meiotic recombination initiation Curr Top Dev Biol 2001, 52:1-53.

134. Paull TT: Making the best of the loose ends: Mre11/Rad50 complexes and Sae2 promote DNA double-strand break resection. DNA Repair 2010, 9:1283-1291.

135. Langerak P, Mejia-Ramirez E, Limbo O, Russell P: Release of Ku and MRN from DNA ends by Mre11 nuclease activity and Ctp1 is required for homologous recombination repair of double-strand breaks. PLoS Genet 2011, 7:e1002271.

136. DeFazio LG, Stansel RM, Griffith JD, Chu G: Synapsis of DNA ends by DNAdependent protein kinase. EMBO J 2002, 21:3192-3200.

137. Weterings E, Verkaik NS, Bruggenwirth HT, Hoeijmakers JH, van Gent DC: The role of DNA dependent protein kinase in synapsis of DNA ends. Nucleic Acids Res 2003, 31:7238-7246.

138. Pawelczak KS, Andrews BJ, Turchi JJ: Differential activation of DNA-PK based on DNA strand orientation and sequence bias. Nucleic Acids Res 2005, 33:152-161.

139. Hammarsten O, DeFazio LG, Chu G: Activation of DNA-dependent protein kinase by single-stranded DNA ends. J Biol Chem 2000, 275:1541-1550.

140. Jovanovic M, Dynan WS: Terminal DNA structure and ATP influence binding parameters of the DNA-dependent protein kinase at an early step prior to DNA synapsis. Nucleic Acids Res 2006 34:1112-1120.

141. Dobbs TA, Tainer JA, Lees-Miller SP: A structural model for regulation of NHEJ by DNA-PKcs autophosphorylation. DNA Repair 2010, 9:1307-1314. 
142. Block WD, Yu Y, Merkle D, Gifford JL, Ding Q, Meek K, Lees-Miller SP: Autophosphorylation-dependent remodeling of the DNA-dependent protein kinase catalytic subunit regulates ligation of DNA ends. Nucleic Acids Res 2004, 32:4351-4357.

143. Reddy YV, Ding Q, Lees-Miller SP, Meek K, Ramsden DA: Non-homologous end joining requires that the DNA-PK complex undergo an autophosphorylation-dependent rearrangement at DNA ends. J Biol Chem 2004, 279:39408-39413.

144. Cui X, Yu Y, Gupta S, Cho YM, Lees-Miller SP, Meek K: Autophosphorylation of DNA-dependent protein kinase regulates DNA end processing and may also alter double-strand break repair pathway choice. Mol Cell Biol 2005, 25:10842-10852

doi:10.1186/2041-9414-3-10

Cite this article as: Strande et al:: Resolution of complex ends by non-

homologous end joining - better to be lucky than good?. Genome

Integrity 2012 3:10.

\section{Submit your next manuscript to BioMed Central and take full advantage of:}

- Convenient online submission

- Thorough peer review

- No space constraints or color figure charges

- Immediate publication on acceptance

- Inclusion in PubMed, CAS, Scopus and Google Scholar

- Research which is freely available for redistribution 